THEORY AND HISTORY OF LAW ENFORCEMENT

DOI 10.24147/2542-1514.2020.4(3).5-15

\title{
RUSSIA: PROPERTY AND STATE. THE HISTORY OF POST-SOVIET LAW ENFORCEMENT (Part I)
}

\author{
Alexander V. Butakov \\ Dostoevsky Omsk State University, Omsk, Russia
}

\section{Article info}

Received -

2020 June 07

Accepted -

2020 August 20

Available online -

2020 October 01

\section{Keywords}

Way of organizing property, normative structuralism, Soviet socialist property, law enforcement ontology, privatization, property, Constitution, post-Soviet Russia
The subject. The relevance of the article is stipulated by the gap in the study of property and the state as a consistent system.

The purpose of the article is to confirm or disprove the hypothesis that each way of organizing property such as private, mixed (corporate) and general (collective) potentially stimulates the existence of a certain state structure.

The methodology. The author uses normative structuralism. This methodology is created by the author and is based on the idea that property as the main system-forming goal of the state's existence genetically predetermines principles of rationing its structure.

The main results of the research. Each way of organizing property in a particular social time period can acquire the quality of the main backbone in the organization structure of the state. Each way of organizing property provides proper social function: private way of organizing property provides function of social development; mixed (corporate) way provides function of social compromise (convergence); general (collective) way provides function of social security in the broadest sense. If private way of organizing property genetically programmed for the production and reproduction of social competition, mixed (corporate) and common (collective) ways are determined by the idea of its limitations and leveling. When the private way of organizing property becomes the main system-forming one it begins to fully stimulate the existence of a democratic structure of state organization. In turn, when mixed (corporate) and common (collective) ways of organizing property become the main system-forming ones, they stimulate the existence of a wide structural range of state functioning: from various regimes of democratic orientation to specific non-democratic regimes.

Conclusions. The study of property as the main system-forming goal of the state existence through the normative structuralism concept allows us to conclude that that each way of organizing property stimulates the existence of a certain state structure. 


\section{Introduction. Lessons from the Soviet times}

1991 is the year when the world's first socialist state, the Union of Soviet Socialist Republics, descended from the world political stage. A few general observations and judgments that characterize the specifics of that social time.

Today, more and more often you are faced with the position when the collapse of the Soviet Union is defined as the largest geopolitical catastrophe of the twentieth century $[1$, p. 17] is this so? Why did a country with more than 280 million people, with a high level of culture and education, occupying $1 / 6$ of the earth's surface, having a strategic geographical location, possessing untold natural resources, and finally having the world's largest nuclear weapons potential, collapse overnight like a house of cards? A country where in 1990, 85618113 (i.e. almost every fifteenth citizen of the USSR) were members of the Communist party and represented the vanguard of the Soviet people, add to this a multi-million-strong army of members of the Komsomol. They all watched the state in silence, as if it were a sinking Titanic.

The natural perception of such an outcome was due to the occurrence of a number of objective phenomena, each of which formed a whole that characterizes the total inevitability of what happened.

First, since the beginning of the 70s, the country has steadily fallen behind the advanced capitalist countries with competitive market economies in terms of production growth and labor productivity, without fulfilling its own social and economic development plans five years after five years (see, for example: [2; 3, p. 388]). Monopolization of forms of the collective way of organizing property has reached its maximum. The mobilization resource of the forms of the General (collective) way of organizing property has essentially dried up. The economy ceased to accept the ideological doctrinality of the Marxist-Leninist doctrine, passing to existence through various forms of rent-seeking. Simply put, blat has become the main mechanism for ensuring the functioning of production: who has more limits, that and the leader. All new science-intensive high-tech production has become incompatible with the already existing total system of rent - seeking and its universal law: "Don't get involved in heroes, if necessary-they will call you."

Second, the country has become a country of universal distribution. As you know, the forms of the General (collective) way of organizing property are conditioned by the action of the social security function. In the Soviet version, the elimination of the private way of organizing property with the function of social development and the subsequent monopolization of the General (collective) way of organizing it naturally reduced the economic possibilities of implementing the function of social security. At the same time, there was an objective increase in the social needs of citizens, which became more and more difficult to meet every year. At a certain stage of socialist construction, the country was forced to move to the formation of a system of universal rationing in distribution. Thus, by the end of the 80 's, it switched to a card distribution system for all major vital products [4, c. 593; 5, c. 239]. Each of us then fully felt the meaning of this universal distribution system with its universal law: "when", "to", "how much" and "in one hand".

Third, a country with a system of universal distribution has become a country of universal deficit [6]. Real control over the movement of scarce goods and related services turned specific Soviet citizens into carriers of a kind of internal ersatz currency, which, on the one hand, depending on the volume and quality of scarce goods and services, provided them with 
stratification growth in the categories of "the right person", "the very right person", "the person who decides everything"; on the other hand, it formed a very narrow specific list of specified goods and services that acquired the quality of a universal equivalent, often making the function of a monetary means of payment secondary. Under the influence of universal distribution and universal scarcity, a specific system of social inequality began to form, which was no longer based on the principle of "from each according to ability, to each according to work", but on the proximity of the citizen to the production, exchange, distribution and consumption of scarce goods and services, with the well - known saying of the time: "don't ask what salary-ask what warehouse".

Fourth, a country with universal unproductivity of labor, with a universal card distribution, with a universal deficit, with a new system of social inequality, due not to labor, but to participation in the distribution of scarce goods and services..., gave rise to a sense of social hopelessness among ordinary Soviet citizens. The lack of a social development perspective was especially accumulated against the background of consumer abundance in capitalist countries with competitive market economies. In the minds of Soviet citizens there was a complex social contradiction, where at the same time our country is the greatest, the strongest, the most beautiful, and immediately-food cards, coupons, endless queues, speculation, corruption, official lies... As a result, double social standards were formed, which became widespread. The cultural and moral values of the Builder of communism have lost their original meaning.

Fifth, a country where the Marxist-Leninist ideology as a fundamental element of the mobilization resource for the implementation of social management has ceased to be such. A mass Exodus of Soviet citizens from members of the Communist Party of the Soviet Union (CPSU) began [7, p. 49; 8], although just 10 years ago they were "jostling in a tight queue" in order to join its ranks. Ideological totality was being destroyed before our eyes. The CPSU was turning into an object for political anecdotes and fables, for each of which, even 30 or 40 years ago, it was safe to secure a long term of imprisonment. The Soviet people, figuratively speaking, "lost all fear", that is, what for many decades of the state's existence was to a decisive extent the exclusive method of social management. For the slave - fear, for the citizen-shame, such was the evolution of the consciousness of our countrymen. The departure of the Soviet Union into political oblivion was so natural that the multi-ethnic and multi-million-strong Soviet people said goodbye to it, tacitly agreeing with the futility of its existence. The people were truly silent.

The forcible elimination of the private way of organizing property and the monopoly of the forms of the general (collective) way of organizing it potentially stimulated the formation of such a structure of the Soviet state, through which the alienation of man from labor, property and power reached absolute values. This is called " what we fought for, we ran into." The Soviet state in the truest sense destroyed the social interest of man to be a citizen, that is, to work freely, to have and dispose of his property freely, to choose his place of residence and occupation freely, to have and Express his opinion freely, to participate freely in the solution of state, municipal and public questions.

Conspiracy theories about the destruction of the Soviet Union by some external and internal enemies [9-11] are "arguments in favor of the poor", who did not understand why our country was in such a sad social situation. We can Express our most sincere words of gratitude to our compatriots for their human wisdom and 
long-suffering, because they did not allow us to transform the peaceful collapse of the Soviet state into a disastrous civil war.

2. The property and the state: at the beginning of the post-Soviet path

The elections of The Congress of people's deputies of the RSFSR in 1990 and President Boris Yeltsin in 1991, in a certain sense, drew a political line under the existence of the Soviet Union and the CPSU. The post-Soviet present has arrived. Neither the people nor the leaders knew what to do next. There was only an understanding that you can't live the way you used to live.

Before our eyes (the eyes of our contemporaries), as a single moment from the point of view of human civilization, the stormy and bright social life of the Soviet state passed as one of the periods of the centuries-old existence of the Russian state. The Soviet experience has shown that the length of the historical activities of a particular method of organizing the structure of the state in a certain way depends on the functioning mode of organization of ownership, the combination of the main ways of its organization or lack thereof. The uniqueness of the Soviet, more than seventy-year-old practice of socialist state building is that it has shown its social futility in the conditions of monopolistic functioning of forms of common (collective) way of organizing property. The existence of a combination relationship and interaction of the main ways of organizing property: private, mixed (corporate), General (collective) - is the dominant condition for the life of the modern state. The parameters of the existence of this combination state are determined by which of the ways of organizing property in a particular social time acts as the main system-forming one, which creates a priority for the implementation of the corresponding social function.
Each way of organizing property can reproduce only a certain social function: a private way of organizing property - a function of social development; mixed (corporate) - a function of social compromise (convergence); general (collective) - a function of social security in the broadest sense. The effect of this dependence is clearly demonstrated by the Soviet experience of socialist state-building, where ideological desire to impose on the monopoly of the forms of the common (collective) way of organizing ownership of the simultaneous implementation of the social development and social compromise (convergence) and functions of social security determined the social collapse of the existence of this state.

The understanding that a certain legalization of the private way of organizing property and a competitive market economy is simply a social necessity came to the highest party-state nomenclature in the late 1980s [12]. But it was too late. The time allowed by history for the Soviet socialist experiment has expired. With the end of the Soviet Union, the majority of our fellow citizens became aware of the need for the Russian state to transition to a competitive market economy based on the functioning of a private way of organizing property. Moreover, there was a certain state of social euphoria that led Russian society into a kind of mental trap.

We, the multi-ethnic and multi-millionth Russian people, having peacefully sent the Soviet socialist state from the political forefront, on the level of everyday mentality "suddenly" felt that we were able to turn the existing social way of life around in the blink of an eye. We are so educated, strong, brave, able to win everything and everyone. For us, moving the Rubicon to a competitive market economy, private property and democracy was the solution to the problem of literally "four hundred days", "five hundred days". Or a little less, or a little more - in General, somewhere 
ISSN 2658-4050 (Online)

like that. We suddenly forgot that modern capitalist society needed several centuries of fierce social competition to create the conditions for the functioning of a free democratic state, in the process of which the private way of organizing property and a competitive market economy reached the current quality of high-tech development.

Along with this process of evolution of the private way of organizing property and conducting a competitive market economy, the corresponding centuries-old evolution of the formation of social and cultural values of man and citizen naturally took place, the implementation of which naturally led to the existence of a free democratic state. Our consciousness did not cover the fact that the modern free democratic state is a reality of centuries - old existence, where society has constructed such a combination of ways of organizing property, in which the private method continuously performed the function of social development as the main, systemforming one.

It was a long road that involved solving many socio-economic, political and cultural problems, which often took the form of severe social conflicts and revolutions. In the process of evolutionary movement was a reconfiguration of social relationships and interaction ways of organizing ownership, thereby forming the corresponding proportions of the implementation of the relationship between community development and social compromise (convergence), social security. All this historical process of movement was conditioned by the permanent existence of social competition, which was the natural generator of the appropriate setting for determining the optimal proportions of the ratio of these social functions, reproduced by appropriate methods of property organization.

The Russian society had a fundamentally different genetics of origin and existence. For the Russian state, traditionally, and especially during the period of its Soviet functioning, the dominant prerogative of forms of common (collective) way of organizing property was an integral social reality. All this determined the state's focus on all-round restriction and leveling of social competition, thus determining the permanent functioning of the undemocratic way of organizing its structure. The dominance of the forms of the common (collective) way of organizing ownership objectively reproduced the existence of relevant disparities between community development and social compromise (convergence), social security in their implementation, since the effect in these circumstances of a private way of organizing ownership was reduced to its limited admissibility, or to enforced liquidation.

The forcible elimination of the private way of organizing property excluded the function of social development. At the same time, there was a hypertrophied transformation of the social security function, the effect of which was subjectively expanded as if to a universal one, capable of reproducing both social development and social compromise (convergence). In reality, the government, acting on the basis of the dominance of forms of the common (collective) way of organizing ownership, in every possible way tried ideological way to encourage maximizing the mobilization of resource through which to provide performance as a function of social development and social compromise (convergence) in the absence of this objective began in the form of private and mixed (corporate) methods of the organization of ownership.

Here the Russian post-Soviet state in a certain sense "suddenly", that is, having only historical experience of dominating the forms of the General (collective) way of organizing property, decided to fundamentally change the stratagem of its existence, where the private and mixed (corporate) ways of organizing 
property in accordance with public perceptions should have acted, if not as the main systemforming ones, then at least be on a par with the existing forms of the General (collective) way of organizing it.

Said and done. In 1990, the popular programs "400 days of trust" (G. A. Yavlinsky, A. Yu.Mikhailov, M. M. Zadornov...), "500 days" (S. S. Shatalin, G. A. Yavlinsky...) appeared [13], in which day after day, week after week, month after month described the transformational transition from the Soviet planned economy to a competitive, socially oriented market [14; 15]. This transition methodology has been variously interpreted in numerous regulations.

3. The process of privatization before the adoption of the Constitution of the Russian Federation in 1993

Consider the normative ontology of the formation of property rights and privatization of state and municipal enterprises in the RSFSR until the adoption of the Constitution of the Russian Federation in 1993.

Thus, Article 2 of the law of the RSFSR No. 443-1 "on property in the RSFSR" dated December 24, 1990 stated that "property rights in the RSFSR are recognized and protected by law, and property may be in private, state, municipal property, as well as in the property of public associations (organizations)".

This normative legal act, firstly, regulates the legislative parity between the forms of private and General (collective) ways of organizing property; secondly, it provides a detailed description of the forms of General (collective) ways of organizing property (state, municipal, public associations (organizations)); third, it is not allowed for the state to impose any form of restrictions or advantages in the exercise of property rights, depending on the location of property in private, state, municipal property and the property of public associations (organizations); fourth, the list of property objects is defined ("enterprises, property complexes, land plots, mining allotments, buildings, structures, equipment, raw materials, money, securities, other property of industrial, consumer, social, cultural and other purposes, as well as products of intellectual and creative work...").

On July 3, 1991, the RSFSR Law No. 1531-1 "On privatization of state and municipal enterprises in the RSFSR" was adopted, where Article 1 "The concept of privatization of state and municipal enterprises" for the first time at the legislative level fixed the normative parameters of this social phenomenon:

"Privatization of state and municipal enterprises - acquisition by citizens, joint-stock companies (partnerships) from the state and local Councils of people's deputies in private ownership of enterprises, workshops, productions, sites, other divisions of these enterprises allocated to independent enterprises; equipment, buildings, structures, licenses, patents and other tangible and intangible assets of liquidated enterprises and their divisions; shares (units, shares) of the state and local Councils of people's deputies in the capital of joint-stock companies (partnerships); shares (units, shares) owned by privatized enterprises in the capital of other joint-stock companies( partnerships), as well as associations, concerns, unions and other associations of enterprises...»

Here, Article 3 of the State privatization program regulated the following provisions:

"1. The goals, priorities and limitations of privatization in the RSFSR are set by The state program of privatization.

The program is introduced by the Council of Ministers of the RSFSR and approved by the Supreme Council of the RSFSR no later than one month before the first reading of the law on the Republican budget of the RSFSR. 
The program is developed for the next three years and consists of a task for the current year and a forecast for the next two years...

3. the program establishes a list of stateowned enterprises, associations or their divisions that are not subject to privatization. This list is coordinated with the republics of the RSFSR, territories, regions, Autonomous regions, Autonomous districts, the cities of Moscow and Leningrad and is approved annually by the Supreme Council of the RSFSR...»

On July 3, 1991, simultaneously with the RSFSR Law No. 1531-1 "on the privatization of state and municipal enterprises in the RSFSR", the RSFSR Law No. 1529-1 "on registered privatisation accounts and deposits in the RSFSR" was adopted, the implementation of which, for reasons of principle, was blocked by the Executive power of the Russian Federation. This is evidenced by the presidential Decree of 29 January 1992, No. 66 "On acceleration of privatization of state and municipal enterprises", decree of the President of the Russian Federation of 14 August 1992914 "on the introduction of the system of privatisation checks in the Russian Federation", Decree of the President of the Russian Federation of October 7, 1992 No. 1186 "on measures to organize the securities market in the process of privatisation of state and municipal enterprises" and, finally, Decree of the President of the Russian Federation of December 24, 1993 No. 2284 "on the State program for privatisation of state and municipal enterprises in the Russian Federation".

The drama of the political struggle between the legislative and Executive authorities in the period from 1991 to 1993 logically ended with the implementation of a coup d'etat on the basis of the illegitimate Decree of the President of the Russian Federation No. 1400

\section{of September 21, 1993 "on gradual} constitutional reform in the Russian Federation". Simply, the nomenclature and bureaucratic machine of the Executive power of the Russian Federation turned out to be more mobilized, more organized, and more economically and resourcefully secured in comparison with the legislative one.

As for the privatization of state and municipal enterprises, in the course of this political struggle, it has acquired completely different normative contours, gradually turning from a national one into a nomenclature-bureaucratic one, which has finally acquired, as the people aptly remark, the character of "prikhvatization".

First, note that the Commission of the nomenclature-bureaucratic coup has once again confirmed that it is a universal mechanism for the continuity of state power in a country where the General (collective) way of organizing property acts as the main system-forming one.

Secondly, in the course of this political struggle, an illegitimate opposition of the authorities arose, as a result of which the technology for privatizing state and municipal enterprises in Russia has changed fundamentally. If the Supreme Soviet in accordance with The law of the RSFSR of July 3, 1991 No. 1531-1 "on the privatization of state and municipal enterprises in the RSFSR" and the Law of the RSFSR of July 3, 1991 No. 1529-1 "On personal privatization accounts and deposits in the RSFSR" strategic directions of privatization was established with the introduction of personal privatization accounts and deposits, the Russian President signed a decree dated 14 August 1992 No. 914 "About introduction in action of system of privatisation checks in the Russian Federation" fundamentally different way directed the privatization of state and municipal enterprises, publicly ignoring the effect of these acts of the Supreme Soviet of the RSFSR.

Third, if the privatization of state and 
municipal enterprises through the introduction of personal privatization accounts and deposits was a continuing legal relationship with the fixation of the citizen's property rights in accordance with the individual labor contribution, the introduction of privatization through personal checks was a one - time legal relationship with a limited time (since December 1, 1992 to December 31, 1993) without fixing the citizen's property rights and accounting for individual labor contributions (each citizen of the Russian Federation-a check with a nominal value of 10,000 rubles).

Fourth, privatisation in accordance with presidential decree No. 914 of August 14, 1992 "on the introduction of the system of privatisation checks in the Russian Federation" was an operation whose strategic goal was the widespread destruction of socialist state property. As for the multi-ethnic and multimillion Russian people, "they did not have property - and you do not need to get used to it." It is clear that the initial accumulation of capital throughout the history of civilization has in a certain sense always been bandit, when social inequality reached critical values. In General, " everyone seems to be 10,000 rubles - and be happy, and we will divide the property ourselves according to nomenclature and bureaucratic concepts." Hence, in the public consciousness of the Russian people, the privatization of state and municipal enterprises has acquired the status of predatory, and the formed private way of organizing property is steadily associated with something illegal and thievish.

\section{Issues of ownership in the Constitution of the Russian Federation 1993}

With this vague attitude to property, the country came to the adoption of the new Constitution of Russia in a national referendum on December 12, 1993. What do we see in the Constitution of the Russian
Federation in 1993 from the point of view of the Constitution of property as the main systemforming goal of the Russian state?

Let's start with the fact that the term "privatization" is not used in the text of the Constitution of the Russian Federation. The nomenclature bureaucracy, apparently, considered that the problem of privatization in its understanding has already been solved once and for all.

The term "property" is used in the text of ten Articles of the Constitution of the Russian Federation. The first two Articles on property regulation are located in Chapter 1 "Fundamentals of the constitutional system" and already by virtue of Article 135 of the Constitution of the Russian Federation have a basic fundamental significance.

It is interesting to conduct a comparative analysis of the semantic content of paragraphs 1 and 2 of this Article.

Everything is more or less clear about "ensuring the unity of the economic space, the free movement of goods, services and financial resources", but as for supporting competition and freedom of economic activity, questions arise here. What is this competition that needs to be maintained? How do I support it? In the name of what to support? Who will support you? If the private way of organizing property is a kind of "natural factory" for the production and reproduction of social competition, then the General (collective) way of organizing it is a different natural factory, but this is to limit and level social competition. What are we going to support?

The ambiguity in the position of support for competition is compounded by the subsequent term "freedom of economic activity". What is the freedom of economic activity when providing support for competition under unspecified rules? If this is freedom of economic activity, then it is simply freedom and competition in this sense is the natural 
mechanism for ensuring it. If this competition is supported, it is already managed by someone. Then there is simply no freedom.

From the point of view of the questions raised, we will consider the content of the text of paragraph 2: "in the Russian Federation, private, state, municipal and other forms of property are recognized and protected equally." There are also certain semantic slyness that can create negative legal consequences.

First, who exactly recognizes this and how?

Second, what is it to recognize and protect "equally"? Each method of organizing property has its own social function: private-the function of social development; mixed (corporate) - the function of social compromise (convergence); General (collective) - the function of social security. Therefore, it is impossible to determine the criteria of equality and inequality in the implementation of these functions, in order to implement the constitutionally enshrined equal principle of their recognition and protection.

Third, paragraph 2 of this Article lists: "private, state, municipal and other forms of ownership". That is, the property of public associations (organizations), joint-stock, cooperative, confessional, etc.for some reason lose this equal image.

All this creates a variety of political meanings and speculations around property. You can't play politics with property. It is the main system-forming goal of the state. If this goal is unclear, then you will get a similar state, whose resources will primarily be used not by the people, but by the nomenclature of the state bureaucracy.

Although it was possible to fix: "property in the Russian Federation is sacred and inviolable" - without arranging various political "exercises" around it.

Political slyness is also fully present in the content of Article 9 of the Constitution of the Russian Federation:

"1. Land and other natural resources are used and protected in the Russian Federation as the basis of life and activity of the peoples living on the relevant territory.

2. Land and other natural resources may be in private, state, municipal and other forms of ownership."

What is land and natural resources as the basis of life and activity of the peoples living in the respective territory? This approach can only mean that, first, "land and other natural resources" is an exceptional phenomenon, the extension of the jurisdiction of the institution of property is in a certain sense a social assumption. Secondly, the formula "land and other natural resources" "as the basis for the life and activities of peoples living in the relevant territory" determines the special position and role of indigenous peoples in the use and protection of these resources. This implies their claim to receive a certain social and material rent. Third, the state voluntarily or unwittingly begins to rank its citizens according to ethnicity, thus forming various components of the ratio of inequality and equality in the place of residence (see paragraph 2 of Article 19 of the Constitution of the Russian Federation).

The wording of paragraph 2 of Article 9 "Land and other natural resources may be in private, state, municipal and other forms of ownership" has a significant semantic resource of political guile. If land and natural resources may be in private, state, municipal, or other forms of ownership, then land and natural resources may not be in each of these forms of ownership, or they may be removed from civil rights circulation altogether. This diversity of legal possibilities for dealing with land and natural resources allows the nomenclature of the state bureaucracy to use this resource primarily for its own narrow-corporate political purposes, including "turning on" and "off " ethnic 
selfishness when necessary.

4. Conclusions.

Each way of organizing property encourages the existence of a certain state structure. Moreover, this process has an evolutionary character. Law-making and law enforcement practice in the first years of post-Soviet Russia clearly demonstrates that the revolutionary introduction of new ways of organizing property leads to an imbalance in the state organization of society. 


\section{REFERENCES}

1. Andreev E. M. New social reality: methodological problems of integrative socio-philosophical and sociological analysis. Obshchestvo i pravo = Society and law, 2009, no. 5, p. 13-20.

2. Orlov B.P. Goals of medium-term plans and their implementation. Ekonomika i organizatsiya promyshlennogo proizvodstva = ECO Journal, 1987, no. 11, p. 34-53.

3. Kazannik A. I., Kostyukov A.N. (eds.). Constitutional law. University course. Textbook. Vol. 1. Moscow, Prospekt, 2015. 432 p.

4. Sulakshin S.S. (ed.). State economic policy and economic doctrine of Russia. Towards a smart and moral economy. Vol. 2. Moscow, Scientific Expert Publ., 2008. 1048 p. $471 \mathrm{p}$.

5. Kudrov V.M. (ed.). Europe and Russia: experience of economic transformations. Moscow, Nauka Publ., 1996.

6. Bychkov A.I. Legal regulation of the economy of joint consumption. Moscow, Infotropik Media, 2019. 136 p.

7. Mokhov V.P. Nomenclature as a political institution in the history of Soviet society in the second half of the XX century, in: Mokhov V.P. (ed.). Nomenclature and nomenclature organization of power in Russia of the twentieth century. Perm, Perm State Technical University Publ., 2004. P. 33-50.

8. Shakhray S.M. Constitutional law of the Russian Federation. Moscow: Statut Publ., 2017. 624 p.

9. Isakov V.B. Who and how broke up the USSR. Chronicle of the largest geopolitical catastrophe of the twentieth century. Moscow, Knizhniy Mir Publ., 2012. 379 p.

10. Khasbulatov R.I. Half-Life of the USSR. How the superpower was destroyed. Moscow, Yauza Press, 2011. $509 \mathrm{p}$.

11. Ryzhkov N.I. The main witness. The case of the collapse of the USSR. Moscow, Algorithm-Book Publ., 2009. $237 \mathrm{p}$.

12. Semenko A.B. Legislative regulation of cooperation as a fundamentally new form of management in the second half of the 1980s and its significance in the liberalization of economic relations in the USSR. Obshchestvo $i$ pravo $=$ Society and law, 2011, no. 5, p. $39-42$.

13. Yavlinskiy G. A., Mikhailov A.Yu., Zadornov M.M. 400 days of trust. Moscow, Nedra Publ., 1990. 61 p.

14. Yasin E.G. Russian economy: course of lectures. Book 1: The origins and panorama of market reforms. Moscow, Higher School of Economics Publ., 2019. 448 p.

15. Andreev V.V. New trends in domestic economic development in the second half of the 1980s - early 1990s (on the example of the republics of the Middle Volga region). Istoriya gosudarstva i prava = History of State and Law, 2009 , no. 18 , p. $25-27$.

\section{INFORMATION ABOUT AUTHOR}

Alexander V. Butakov - Doctor of Law, Professor, Department of Theory and History of State and Law Dostoevsky Omsk State University

55a, Mira pr., Omsk, 644077, Russia

E-mail:magistr25@inbox.ru

RSCI SPIN-code: 9843-0789; AuthorID: 683256

\section{BIBLIOGRAPHIC DESCRIPTION}

Butakov A.V. Russia: property and state. The history of post-Soviet law enforcement (Part I). Pravoprime- nenie = Law Enforcement Review, 2020, vol. 4, no. 3, pp. 5-15. DOI: 10.24147/25421514.2020.4(3).5-15.

(In Russ.). 